\title{
ASAH2 Gene
}

National Cancer Institute

\section{Source}

National Cancer Institute. ASAH2 Gene. NCI Thesaurus. Code C103902.

This gene is involved in sphing olipid-ceramide hydrolysis. 